\section{Association between sociodemographic characteristics and sexual behaviors among a nationally representative sample of adolescent students in Brazil}

\author{
Associação entre características sociodemográficas \\ e comportamentos sexuais em uma amostra \\ nacional representativa de estudantes \\ adolescentes no Brasil
}

\author{
Asociación entre características sociodemográficas \\ y comportamientos sexuales en una muestra \\ nacional representativa con estudiantes \\ adolescentes en Brasil
}




\section{Introduction}

Adolescence is a critical time for sexual development. This period is marked by the onset of puberty, the start of fertility, and, often times, the beginning of sexual activity ${ }^{1}$. Although this development is a natural part of adolescence 2 , if condoms are not used, sexual activity can expose adolescents to sexually transmitted infections (STIs) and unintended pregnancies ${ }^{3}$. Each year, youths below 25 years old account for the largest proportion of new worldwide cases of STIs 4, and the HIV is one of the leading causes of death among people in this age group, especially in African nations 5. Moreover, while adolescent pregnancy has shown a substantial global decline 6, some regions, such as the Sub-Saharan Africa 7 and Latin America 8, have experienced a slower decline.

Brazil, a middle-income country home to 34 million adolescents 9 , has been considered a global model in the prevention and treatment of STI's such as HIV 10. Yet, recent trends in new cases of HIV among adolescents indicate a quasi-doubling in the infection's incidence among 15-19 years old youth (Brazilian Ministry of Health. http://www2.aids.gov.br/cgi/tabcgi.exe?tabnet/br.def, accessed on 02/Jun/2017). Challenges also exist with regard to other STIs, such as the HPV infection, which is a highly prevalent STI 11, but still not well known among many Brazilian adolescents 12 . Moreover, recent budgetary pressures and political turmoil have highlighted the need for more efficient STI preventive efforts in the country 10 .

The adolescent fertility rate in Brazil is also moderately high compared to other countries in Latin America. For instance, Brazil's adolescent fertility rate is higher than Mexico's, Argentina's and Chile's 8 . While fertility among females 15-19 years of age has been decreasing, most of the decline has stemmed from older adolescents, between the ages of 18 and 19 years ${ }^{13}$. In contrast, adolescents 15-17 years old, who in 1991 accounted for 37\% of all the births among 15-19 years old women, in 2010 represented $45 \%$ of all births in this age group ${ }^{13}$. In addition, adolescent pregnancy may disrupt female educational attainment, and in Brazil it is estimated that about one in three pregnant adolescents will have dropped out of school by the time they give birth 14 . Pregnant adolescents may instead opt to terminate their pregnancies and it is estimated that adolescent females account for the highest proportion of induced abortions among women of reproductive age in Brazil 15. The country has broad restrictions on abortions, and pursuing an illegal abortion can pose serious health threats 16 .

Some key sexual behaviors have been identified as proximate factors contributing to both pregnancy and STI risk during adolescence, including age of sexual initiation, sexual intercourse frequency, having multiple sexual partners 17, and inconsistent condom and contraceptive use 17,18.

Low socioeconomic status (SES) among adolescents, as measured by factors such as maternal education and parental income, is also associated with increased risks of STIs and pregnancy 13,19. However, the relationship between low SES and proximate sexual behaviors (e.g., inconsistent condom and contraceptive use) commonly related to STIs and adolescent pregnancy risk is still not well known 17 . For instance, research in the United States did not find significant differences in adolescent sexual behaviors according to SES 18. The researchers concluded that the observed inequalities in STIs and pregnancy rates between SES groups were more likely linked to disparities in access to health care and variation in STIs' prevalence across communities ${ }^{18}$. In Brazil, research on proximate factors and their relationship to SES during adolescence has yielded contradictory results $20,21,22$, potentially due to both the lack of standardization of SES measures and absence of nationwide data on the topic (which would allow for regional variations to be taken into consideration).

This study is interested in expanding on the evidence of the relationship between adolescent SES and sexual behaviors in Brazil. A cross-sectional study was analyzed to investigate the relationship between three fundamental dimensions of socioeconomic status (i.e., household wealth, maternal education, and race/ethnicity), and four adolescent sexual behaviors (i.e., sexual initiation, multiple sexual partners, inconsistent condom use, and inconsistent contraceptive use). The study also assessed the moderating impact of family structure and parental involvement on the relationship between sexual behaviors and socioeconomic status. 


\section{Methods}

\section{Data source}

Data for this study were obtained from the 2015 Brazilian National Survey of School Health (PeNSE) 23, a triennial nation-wide survey, and used to assess health protective factors and risk behaviors among Brazilian adolescents. PeNSE was modeled after the Global School-Based Student Health Survey (GSHS) and the Youth Risk Behavior Surveillance System (YRBSS), which are both widely used surveys to monitor adolescent health behaviors around the world 24 .

A total 102,301 9th grade students across 3,040 schools were included in the 2015 PeNSE 23. The survey encompassed both public and private schools located in urban and rural zones, across all five geographic regions of Brazil 23. The original survey was approved by the Brazilian National Commission on Research Ethics (Conep), and the Brazilian National Health Council (CNS) (report n. 1.006.467 from 30/Mar/2015). De-identified survey data are publicly available at the Brazilian Institute of Geography and Statistics (IBGE) website (http://www.ibge.gov.br). For this reason, this study was considered exempt from further human subjects review. In addition, the IBGE provides sampling weights based on a complex survey design and which were included in the present study to obtain population estimates.

This study builds on previous PeNSE analyses of sexual behaviors among Brazilian adolescent students. The latest studies on the topic were conducted using data from 2009 and 2012, while the present study used the latest available PeNSE survey, from 2015. In addition, previous articles focused on more descriptive statistics of sexual behaviors 22 , or did not investigate students' household possessions as a sociodemographic characteristic potentially related to sexual behaviors 22 . Finally, contraceptive use and its association with students' sociodemographic characteristics has yet to be investigated 22 .

\section{Variable description}

Four sexual behaviors (i.e., dependent variables) were analyzed: (1) sexual initiation (yes/no); (2) condom use at last intercourse (yes/no); (3) use of any contraceptive method during the last intercourse (not including condoms) (yes/no); and (4) multiple sexual partners (yes/no). Regarding the contraceptive use variable, PeNSE's question was worded to exclude use of condoms, possibly to assess exclusive use of other non-hormonal and hormonal contraceptive methods (e.g., diaphragm, contraceptive injections, and the contraceptive pill). The multiple sexual partners variable was based on whether adolescents had two or more sexual partners during their lifetime (yes), in line with previous analyses on the topic 18 .

Sexual behavior patterns were examined using three measures of adolescent SES, given that different SES measures have yielded different results in previous studies 25. The first SES component, household wealth index, was obtained through a survey-weighted principal component analysis (PCA) of students' household possessions and other markers of wealth. A total of nine variables were used in the construction of this index including household ownership of a car, motorcycle, computer, landline telephone, internet access, student ownership of a cellphone, private school attendance, household employment of a domestic worker, number of bathrooms with a shower in the house, and number of household residents. The resulting index was divided into wealth quintiles, with the first quintile referring to the $20 \%$ richest and the fifth quintile to the $20 \%$ poorest adolescents.

The second SES variable, maternal education, included three categories: "no education", "high school or less", and "some college or more". A sizeable number of students replied not knowing about their mother's education ( $N=25,183)$. To address this issue a multiple imputation procedure, using relevant sociodemographic characteristics (i.e., household wealth index, and race/ethnicity), was performed to impute meaningful maternal education values into this variable. The third SES variable, race/ethnicity, was included due to considerable evidence of racial/ethnic inequalities in income and living standards in Brazil 26. The variable was self-reported and had four categories; "white", "black", "mixed-race", and "other" (i.e., Asian and indigenous). 
Some family characteristics are also important to adolescents' sexual development since parents can play a key role by providing information, support, and setting limits and expectations 27. Two parent-related variables were included in the analysis to capture family structure and parental involvement, and potential moderation in the relationship between SES and sexual behaviors. Living arrangements assessed whether students lived alone, only with the mother, only with the father, or with both parents. Frequent parent supervision (yes/no) captured adolescents' assessment of how often parents got to know about their activities outside school in the prior 30 days. Answers "never", "rarely", and "sometimes" were coded as "no", and answers "most of the time" and "always" were coded as "yes". Additional demographic covariates and potential confounders were also taken in consideration, including sex (male/female), age (13 or younger, 14, 15, 16, 17, and 18 or older) and geographic region (urban/rural).

\section{Analytical plan}

Weighted percentages and 95\% confidence intervals (95\%CI) were calculated for all variables. Descriptive statistics were stratified by sex in order to inspect potential differences between males and females. Logistic models were run, and unadjusted odds ratios (aOR) and confidence intervals were inspected for each focal relationship between one SES variable and one sexual behavior (e.g., maternal education as the predictor variable, and sexual initiation as the outcome variable).

After testing for multicollinearity among the three SES variables (mean VIF $=1.1$ ), them were included into one model, which also involved geographic region, age and family characteristics, to analyze each adolescent sexual behavior and to assess changes in magnitude and significance of SES coefficients. All analyses included survey design weights to account for the survey's complex sample design, by using the "svy" command in Stata 14.0 (https://www.stata.com). Survey weights were used to obtain population estimates for all noninstitutionalized 9th grade students in Brazil.

\section{Results}

About $48.3 \%$ of the adolescent students were males and 51.7\% females. Most adolescents were between 14 and 15 years old, as expected in a sample of 9th grade students (Table 1). The majority lived in urban areas (92\%). Regarding SES measures, females and males were equally distributed across all five household wealth index percentiles. Most students had mothers with high school education or less (51.2\% for females and $48.6 \%$ for males). Finally, mixed-race adolescents comprised the largest racial group for both females and males (46\% and 39.9\%, respectively), followed by whites and blacks.

About 27.5\% (95\%CI: 27.0-28.0) of adolescents were sexually initiated, and among those, approximately one in two did not use any contraceptive method during the last intercourse $(53.2 \%, 95 \% \mathrm{CI}$ : 51.4-54.9 for females, and 57.9\%, 95\%CI: 56.5-59.3 for males). Condom use was more widespread among both sexes, even though about one in three adolescents did not use condoms during the last intercourse (33.1\%, 95\%CI: 31.5-34.8 for females, and 30.5\%, 95\%CI: 29.2-31.7 for males). In addition, a large difference between males and females was observed in multiple sexual partners rates. Around 45.2\% (95\%CI: 43.5-46.9) of female adolescents had more than one sexual partner over their lifetime, while that percentage was $73.6 \%$ (95\%CI: 72.5-74.8) for males.

Unadjusted logistic regressions for each SES variable highlighted different patterns of association with sexual behaviors among males and females (Table 2). Among females, all three SES variables were consistently associated with one sexual behavior (i.e., sexual initiation). For instance, females in the top household wealth quintile had lower odds of sexual initiation compared to females in the lower quintiles.

In contrast with females, among males one SES variable, race/ethnicity, was consistently associated with multiple sexual behaviors (i.e., sexual initiation, condom use, and number of sexual partners). For instance, compared to white males, black and mixed-race adolescents had significantly higher odds of sexual initiation and having multiple sexual partners, but lower odds of condom use.

All three SES variables were combined to further analyze adolescent sexual behaviors for both females and males. Covariates for geographic region, age and family characteristics were also includ- 
Table 1

Weighted percentages and $95 \%$ confidence intervals $(95 \% \mathrm{Cl})$ of the distribution of Brazilian adolescent students by sex. Brazilian National Survey of School Health (PeNSE), 2015.

\begin{tabular}{|c|c|c|c|c|}
\hline & \multicolumn{2}{|c|}{ Females (weighted $N=1,349,090$ ) } & \multicolumn{2}{|c|}{ Males (weighted $N=1,281,743$ ) } \\
\hline & $\%$ & $95 \% \mathrm{Cl}$ & $\%$ & $95 \% \mathrm{Cl}$ \\
\hline \multicolumn{5}{|l|}{ Demographic measures } \\
\hline \multicolumn{5}{|l|}{ Age (years) } \\
\hline 13 or younger & 20.4 & $19.7-21.1$ & 16.0 & $15.4-16.6$ \\
\hline 14 & 53.2 & $52.4-53.9$ & 48.7 & $47.9-49.5$ \\
\hline 15 & 17.5 & $16.9-18.0$ & 22.2 & $21.6-22.8$ \\
\hline 16 & 5.7 & 5.4-6.1 & 8.7 & 8.3-9.1 \\
\hline 17 & 2.0 & $1.9-2.2$ & 3.1 & $2.9-3.3$ \\
\hline 18 or older & 1.2 & $1.1-1.3$ & 1.3 & $1.2-1.4$ \\
\hline \multicolumn{5}{|l|}{ Geographic region } \\
\hline Rural & 8.5 & $8.2-8.9$ & 8.1 & $7.8-8.5$ \\
\hline Urban & 91.5 & $91.1-91.8$ & 91.9 & $91.5-92.2$ \\
\hline \multicolumn{5}{|c|}{ Family structure and parental involvement } \\
\hline \multicolumn{5}{|c|}{ Living arrangements } \\
\hline Does not live with either parent & 6.5 & $6.1-6.8$ & 4.9 & $4.6-5.2$ \\
\hline Mother only & 32.4 & $31.7-33.2$ & 28.6 & $27.9-29.4$ \\
\hline Father only & 3.4 & $3.2-3.7$ & 5.3 & 4.9-5.7 \\
\hline Both & 57.7 & $56.9-58.4$ & 61.1 & $60.4-61.9$ \\
\hline \multicolumn{5}{|l|}{ Frequent parent supervision } \\
\hline Yes & 69.4 & $68.7-70.1$ & 62.69 & $61.9-63.5$ \\
\hline No & 30.6 & 29.9-31.3 & 37.31 & $36.5-38.1$ \\
\hline \multicolumn{5}{|l|}{ Socioeconomic status measures } \\
\hline \multicolumn{5}{|l|}{ Household wealth index (quintiles) } \\
\hline Bottom & 20.9 & $20.4-21.5$ & 18.1 & $17.5-18.6$ \\
\hline 4th & 20.4 & $19.9-21.0$ & 18.8 & $18.2-19.4$ \\
\hline $3 r d$ & 20.5 & $19.9-21.2$ & 21.0 & $20.4-21.7$ \\
\hline 2nd & 18.9 & $18.2-19.5$ & 21.0 & $20.3-21.7$ \\
\hline Top & 19.3 & 18.6-19.9 & 21.2 & $20.5-21.9$ \\
\hline \multicolumn{5}{|l|}{ Maternal education } \\
\hline No education & 5.6 & $5.3-5.9$ & 5.1 & $4.8-5.5$ \\
\hline High School or less & 51.2 & $50.4-51.9$ & 48.6 & $47.8-49.4$ \\
\hline Some College or more & 17.2 & $16.6-17.8$ & 18.5 & $17.9-19.1$ \\
\hline \multicolumn{5}{|l|}{ Race/Ethnicity } \\
\hline White & 35.0 & 34.2-35.7 & 37.4 & $36.6-38.2$ \\
\hline Black & 11.4 & $10.9-11.8$ & 15.5 & $15.0-16.1$ \\
\hline Mixed-race & 46.0 & $45.3-46.8$ & 39.9 & $39.2-40.7$ \\
\hline Other & 7.6 & 7.3-8.0 & 7.2 & $6.8-7.6$ \\
\hline \multicolumn{5}{|l|}{ Sexual behaviors } \\
\hline \multicolumn{5}{|l|}{ Ever had sex } \\
\hline Yes & 19.6 & $19.0-20.2$ & 36.0 & $35.2-36.7$ \\
\hline No & 80.5 & 79.9-81.1 & 64.0 & $63.3-64.8$ \\
\hline \multicolumn{5}{|c|}{ Use of any contraceptive method during last intercourse * } \\
\hline Yes & 46.9 & $45.1-48.6$ & 42.1 & $40.7-43.5$ \\
\hline No & 53.2 & $51.4-54.9$ & 57.9 & $56.5-59.3$ \\
\hline \multicolumn{5}{|l|}{ Condom use during last intercourse * } \\
\hline Yes & 66.9 & $65.2-68.5$ & 69.6 & $68.3-70.8$ \\
\hline No & 33.1 & $31.5-34.8$ & 30.5 & $29.2-31.7$ \\
\hline \multicolumn{5}{|l|}{$>1$ sexual partners over lifetime * } \\
\hline Yes & 45.2 & $43.5-46.9$ & 73.6 & $72.5-74.8$ \\
\hline No & 54.8 & $53.1-56.5$ & 26.4 & $25.2-27.5$ \\
\hline
\end{tabular}

Source: Brazilian Institute of Geography and Statistics 23.

* Question only asked to students who replied having had sex (female weighted $N=262,764$, male weighted $N=457,482$ ). 


\section{Table 2}

Adjusted odds ratios * for logistic regression of individual sexual behaviors among Brazilian adolescent students. Brazilian National Survey of School Health (PeNSE), 2015.

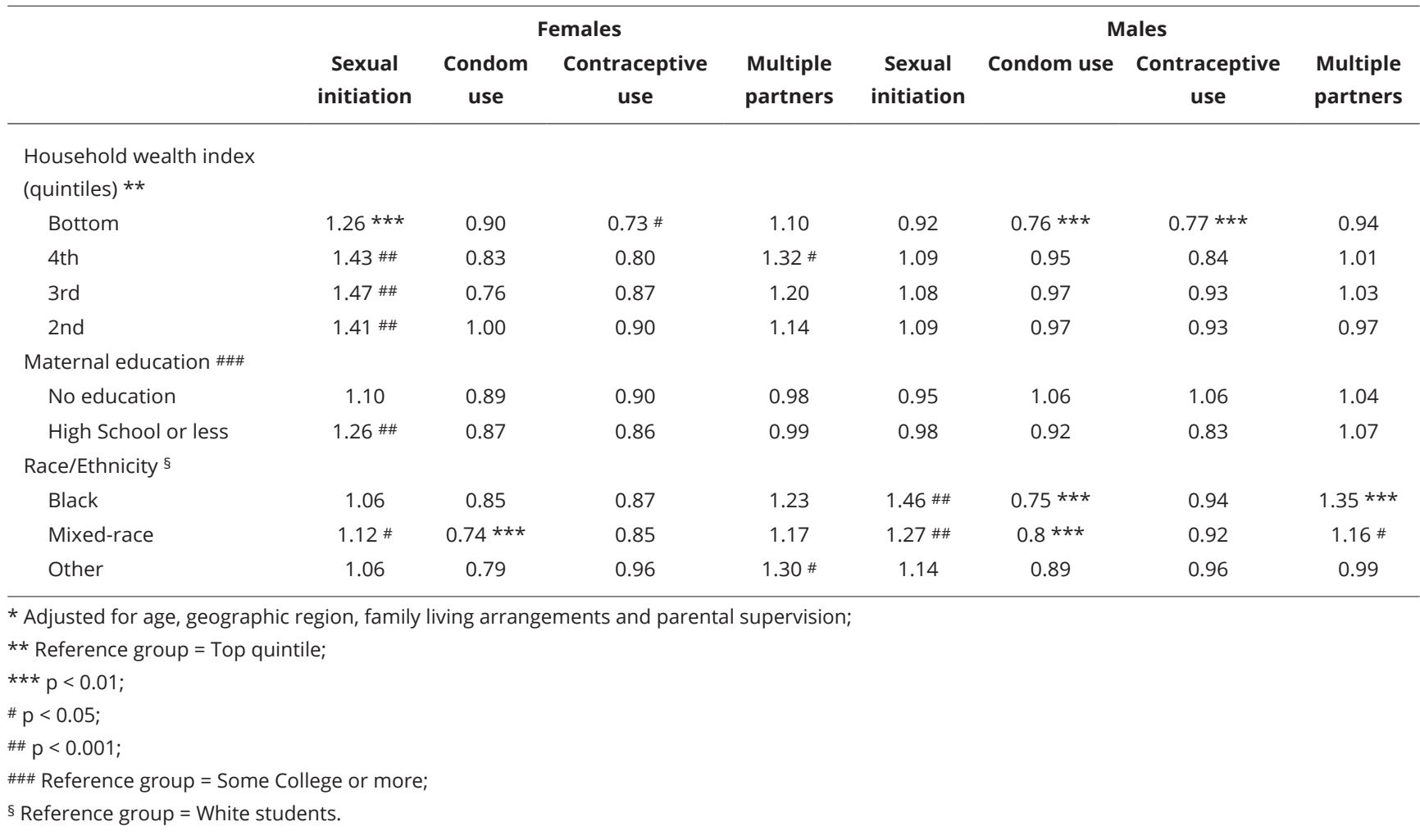

ed in those models. Females in the top household wealth quintile had lower odds of sexual initiation compared to all other categories, even after accounting for maternal education, race/ethnicity, and the other control covariates (Table 3). Odds of sexual initiation for females in the bottom household wealth quintile were $18 \%$ higher compared to those at the top $(\mathrm{aOR}=1.18,95 \% \mathrm{CI}: 1.02-1.39)$. Females whose mothers had only high school education or less also had higher odds of sexual initiation compared to those whose mothers had some college education or more (aOR = 1.17, 95\%CI: 1.02-1.34).

Odds of sexual initiation among females were also positively associated with age and living in an urban setting (Table 3). Moreover, living arrangement and parental supervision were significant predictors of female sexual initiation after accounting for all other factors. For instance, odds of sexual initiation for females living alone were 2.44 times the odds of those living with both parents $(\mathrm{aOR}=2.44,95 \% \mathrm{CI}: 2.12-2.80)$.

Among males, racial/ethnic differences remained significant predictors of sexual initiation, condom use and number of sexual partners, even after accounting for household wealth, maternal education, and the other control variables (Table 4). For instance, compared to white adolescent males, blacks had $48 \%$ higher odds of sexual initiation ( $\mathrm{aOR}=1.48,95 \% \mathrm{CI}$ : $1.32-1.65$ ), 35\% higher odds of having multiple partners $(\mathrm{aOR}=1.35,95 \% \mathrm{CI}: 1.13-1.62)$, and $22 \%$ lower odds of condom use at last intercourse $(\mathrm{aOR}=0.78,95 \% \mathrm{CI}$ : 0.65-0.94).

Other significant SES differences among males were noted between top and bottom household wealth quintiles. Males in the bottom quintile had approximately 33\% lower odds of condom and contraceptive use $(\mathrm{aOR}=0.78,95 \% \mathrm{CI}$ : 0.63-0.97, and $\mathrm{aOR}=0.77,95 \% \mathrm{CI}: 0.62-0.95$, respectively) compared to those in the top quintile. There were no significant differences in sexual behaviors according to maternal education among males.

Lastly, living arrangement and parental supervision were significant predictors of male sexual initiation and condom use. For instance, odds of sexual initiation for adolescent males living alone were 1.68 times the odds of those living with both parents ( $\mathrm{aOR}=1.68,95 \% \mathrm{CI}: 1.45-1.94)$. 


\section{Table 3}

Adjusted odds ratios $(\mathrm{aOR})$ and $95 \%$ confidence intervals $(95 \% \mathrm{Cl})$ of sexual and reproductive behaviors among Brazilian adolescent females. Brazilian National Survey of School Health (PeNSE), 2015.

\begin{tabular}{|c|c|c|c|c|c|c|c|c|}
\hline & \multicolumn{2}{|c|}{ Sexual initiation } & \multicolumn{2}{|c|}{ Condom use } & \multicolumn{2}{|c|}{ Contraceptive use } & \multicolumn{2}{|c|}{ Multiple partners } \\
\hline & aOR & $95 \% \mathrm{Cl}$ & aOR & $95 \% \mathrm{Cl}$ & aOR & $95 \% \mathrm{Cl}$ & aOR & $95 \% \mathrm{Cl}$ \\
\hline \multicolumn{9}{|c|}{ Household wealth index (quintiles) } \\
\hline Bottom & 1.18 * & $1.02-1.39$ & 0.97 & $0.72-1.29$ & 0.78 & $0.59-1.03$ & 1.09 & $0.83-1.43$ \\
\hline 4th & $1.33 * *$ & $1.14-1.56$ & 0.87 & $0.66-1.16$ & 0.86 & $0.66-1.12$ & 1.32 * & $1.02-1.72$ \\
\hline $3 r d$ & $1.39 * *$ & $1.19-1.62$ & 0.78 & $0.59-1.04$ & 0.92 & $0.70-1.20$ & 1.20 & $0.93-1.58$ \\
\hline 2nd & $1.35 * *$ & $1.15-1.59$ & 1.03 & $0.77-1.39$ & 0.95 & $0.71-1.26$ & 1.13 & $0.86-1.49$ \\
\hline Top & 1.00 & & 1.00 & & 1.00 & & 1.00 & \\
\hline \multicolumn{9}{|l|}{ Maternal education } \\
\hline No education & 1.05 & $0.85-1.29$ & 0.93 & $0.65-1.33$ & 1.03 & $0.74-1.44$ & 0.94 & $0.67-1.32$ \\
\hline High School or less & 1.17 * & $1.02-1.34$ & 0.92 & $0.72-1.18$ & 0.92 & $0.73-1.17$ & 0.94 & $0.75-1.19$ \\
\hline Some College or more & 1.00 & & 1.00 & & 1.00 & & 1.00 & \\
\hline \multicolumn{9}{|l|}{ Race/Ethnicity } \\
\hline Black & 1.01 & $0.88-1.16$ & 0.86 & 0.67-1.09 & 0.91 & $0.72-1.16$ & 1.18 & 0.93-1.49 \\
\hline Mixed-race & 1.09 & $0.99-1.21$ & $0.76 * * *$ & $0.63-0.91$ & 0.88 & $0.74-1.04$ & 1.16 & $0.98-1.38$ \\
\hline Other & 1.06 & $0.90-1.24$ & 0.79 & $0.59-1.06$ & 0.98 & $0.75-1.27$ & $1.31 *$ & $1.02-1.69$ \\
\hline White & 1.00 & & 1.00 & & 1.00 & & 1.00 & \\
\hline \multicolumn{9}{|l|}{ Age (years) } \\
\hline 13 or younger & $0.49 * *$ & $0.41-0.58$ & 1.23 & $0.85-1.77$ & 0.74 & $0.52-1.05$ & 0.75 & $0.54-1.05$ \\
\hline 14 & 1.00 & & 1.00 & & 1.00 & & 1.00 & \\
\hline 15 & $2.70 * * *$ & $2.45-2.98$ & 0.89 & $0.75-1.08$ & 1.06 & $0.89-1.26$ & $1.41 * *$ & $1.19-1.67$ \\
\hline 16 & $4.94 * *$ & $4.31-5.66$ & 0.88 & $0.71-1.10$ & $1.52 * *$ & $1.23-1.88$ & $1.92 * *$ & $1.55-2.37$ \\
\hline 17 & $5.82 * *$ & $4.81-7.05$ & 0.80 & $0.61-1.06$ & $1.61 * *$ & $1.23-2.11$ & $1.76 * *$ & $1.36-2.29$ \\
\hline 18 or older & $8.13 * *$ & $6.11-10.82$ & 0.92 & $0.63-1.34$ & 1.33 & $0.93-1.91$ & $2.42 * *$ & $1.68-3.49$ \\
\hline \multicolumn{9}{|l|}{ Geographic region } \\
\hline Urban & 1.15 * & $1.01-1.31$ & $0.73 * * *$ & $0.57-0.92$ & 1.11 & $0.89-1.39$ & $1.39 * * *$ & $1.11-1.72$ \\
\hline Rural & 1.00 & & 1.00 & & 1.00 & & 1.00 & \\
\hline \multicolumn{9}{|l|}{ Living arrangements } \\
\hline None & $2.44 * *$ & $2.12-2.80$ & 0.78 * & $0.63-0.98$ & 1.14 & $0.91-1.42$ & 1.08 & $0.87-1.34$ \\
\hline Mother only & $1.71 * *$ & $1.56-1.87$ & 0.91 & $0.76-1.07$ & 0.94 & $0.80-1.10$ & 1.19 & $1.02-1.40$ \\
\hline Father only & $1.78 * *$ & $1.47-2.16$ & 1.01 & $0.72-1.40$ & 1.01 & $0.74-1.40$ & 1.31 & $0.98-1.75$ \\
\hline Both & 1.00 & & 1.00 & & 1.00 & & 1.00 & \\
\hline \multicolumn{9}{|c|}{ Frequent parent supervision } \\
\hline Yes & $0.55 * *$ & $0.49-0.59$ & $1.28 * * *$ & $1.10-1.49$ & 1.11 & $0.96-1.29$ & $0.67 * *$ & $0.58-0.77$ \\
\hline No & 1.00 & & 1.00 & & 1.00 & & 1.00 & \\
\hline $\mathrm{F}$ & \multicolumn{2}{|c|}{103.91} & \multicolumn{2}{|c|}{2.65} & \multicolumn{2}{|c|}{2.31} & \multicolumn{2}{|c|}{6.83} \\
\hline
\end{tabular}

Source: Brazilian Institute of Geography and Statistics 23.

* $p<0.05$;

** $\mathrm{p}<0.001$;

$\star * * p<0.01$. 
Table 4

Adjusted odds ratios (aOR) and $95 \%$ confidence intervals $(95 \% \mathrm{Cl})$ of sexual and reproductive behaviors among Brazilian adolescent males. Brazilian National Survey of School Health (PeNSE), 2015.

\begin{tabular}{|c|c|c|c|c|c|c|c|c|}
\hline & \multicolumn{2}{|c|}{ Sexual initiation } & \multicolumn{2}{|c|}{ Condom use } & \multicolumn{2}{|c|}{ Contraceptive use } & \multicolumn{2}{|c|}{ Multiple partners } \\
\hline & aOR & $95 \% \mathrm{Cl}$ & aOR & $95 \% \mathrm{Cl}$ & aOR & $95 \% \mathrm{Cl}$ & aOR & $95 \% \mathrm{Cl}$ \\
\hline \multicolumn{9}{|c|}{ Household wealth index (quintiles) } \\
\hline Bottom & 0.86 * & $0.76-0.98$ & 0.78 * & $0.63-0.97$ & 0.77 * & $0.62-0.95$ & 0.86 & $0.69-1.07$ \\
\hline 4th & 1.04 & $0.92-1.18$ & 0.98 & $0.79-1.21$ & 0.86 & $0.70-1.05$ & 0.94 & $0.76-1.16$ \\
\hline $3 r d$ & 1.05 & $0.93-1.18$ & 0.99 & $0.79-1.22$ & 0.95 & $0.78-1.17$ & 0.98 & $0.79-1.21$ \\
\hline 2nd & 1.06 & $0.95-1.19$ & 0.99 & $0.80-1.22$ & 0.95 & $0.78-1.16$ & 0.94 & $0.77-1.15$ \\
\hline Top & 1.00 & & 1.00 & & 1.00 & & 1.00 & \\
\hline \multicolumn{9}{|l|}{ Maternal education } \\
\hline No education & 0.96 & $0.81-1.14$ & 1.18 & $0.88-1.59$ & 1.21 & $0.92-1.61$ & 1.08 & $0.82-1.42$ \\
\hline High School or less & 0.96 & $0.87-1.06$ & 0.98 & $0.81-1.19$ & 0.89 & $0.74-1.07$ & 1.08 & $0.91-1.28$ \\
\hline Some College or more & 1.00 & & 1.00 & & 1.00 & & 1.00 & \\
\hline \multicolumn{9}{|l|}{ Race/Ethnicity } \\
\hline Black & $1.48 * *$ & $1.32-1.65$ & $0.78 * * *$ & $0.65-0.94$ & 0.96 & $0.81-1.15$ & $1.35 * \star \star$ & $1.13-1.62$ \\
\hline Mixed-race & $1.29 * *$ & $1.19-1.40$ & 0.83 * & $0.72-0.96$ & 0.95 & $0.82-1.09$ & 1.17 * & $1.01-1.35$ \\
\hline Other & 1.16 * & $1.01-1.33$ & 0.91 & $0.72-1.15$ & 0.99 & $0.79-1.25$ & 0.99 & $0.79-1.26$ \\
\hline White & 1.00 & & 1.00 & & 1.00 & & 1.00 & \\
\hline \multicolumn{9}{|l|}{ Age (years) } \\
\hline 13 or younger & $0.57 * *$ & $0.49-0.65$ & $0.69 * * *$ & $0.54-0.89$ & 1.01 & $0.78-1.31$ & 0.77 * & $0.61-0.97$ \\
\hline 14 & 1.00 & & 1.00 & & 1.00 & & 1.00 & \\
\hline 15 & $2.14 * *$ & $1.96-2.33$ & $1.23 * * *$ & $1.06-1.43$ & $1.23 * * *$ & $1.07-1.42$ & $1.38 * *$ & $1.19-1.59$ \\
\hline 16 & $3.78 * *$ & $3.36-4.25$ & 1.03 & $0.86-1.24$ & $1.43 * *$ & $1.21-1.69$ & $1.50 * *$ & $1.25-1.81$ \\
\hline 17 & $4.65 * *$ & $3.89-5.54$ & 1.20 & $0.96-1.50$ & $1.45 * * *$ & $1.15-1.79$ & $2.53 * \star$ & $1.98-3.24$ \\
\hline 18 or older & 4.72 ** & $3.61-6.19$ & 1.35 & $0.96-1.88$ & $1.42 *$ & $1.05-1.95$ & $1.39 *$ & $1.01-1.92$ \\
\hline \multicolumn{9}{|l|}{ Geographic region } \\
\hline Urban & 0.96 & $0.85-1.08$ & $0.67 * *$ & $0.56-0.82$ & 0.86 & $0.72-1.03$ & 0.83 & $0.69-1.00$ \\
\hline Rural & 1.00 & & 1.00 & & 1.00 & & 1.00 & \\
\hline \multicolumn{9}{|l|}{ Living arrangements } \\
\hline None & $1.68 * *$ & $1.45-1.94$ & 0.81 & $0.64-1.01$ & 0.86 & $0.68-1.08$ & 1.11 & $0.87-1.43$ \\
\hline Mother only & $1.35 * *$ & $1.25-1.47$ & 0.97 & $0.84-1.11$ & 0.97 & $0.85-1.11$ & $1.16 *$ & $1.01-1.33$ \\
\hline Father only & $1.37 * *$ & $1.17-1.61$ & 0.84 & $0.66-1.07$ & 0.99 & $0.79-1.26$ & 1.19 & $0.93-1.52$ \\
\hline Both & 1.00 & & 1.00 & & 1.00 & & 1.00 & \\
\hline \multicolumn{9}{|c|}{ Frequent parent supervision } \\
\hline Yes & $0.53 * *$ & $0.49-0.57$ & $1.33 * *$ & $1.18-1.49$ & $0.88 *$ & $0.78-0.99$ & $0.87 *$ & $0.77-0.98$ \\
\hline No & 1.00 & & 1.00 & & 1.00 & & 1.00 & \\
\hline $\mathrm{F}$ & \multicolumn{2}{|c|}{85.89} & \multicolumn{2}{|c|}{4.33} & \multicolumn{2}{|c|}{2.74} & \multicolumn{2}{|c|}{5.94} \\
\hline
\end{tabular}

Source: Brazilian Institute of Geography and Statistics 23.

$* p<0.05$;

** $p<0.001$;

$* * * p<0.01$.

\section{Discussion}

Overall, while one third of Brazilian adolescent students were sexually experienced, the majority did not use any contraceptive method at last intercourse, and one in three did not use a condom. The present findings indicate different patterns in the association between each individual SES and sexual behavior variables among males and females. These variations underscore the complexities in 
understanding the relationship between these two broad concepts and the challenges of taking into consideration context-specific gender norms, which shape distinct sexual behaviors among males and females.

For instance, household wealth index was not consistently associated with male sexual initiation but was negatively associated with female sexual initiation. This conclusion stands somewhat in contrast with previous region-specific studies in Brazil, which have found an inverse relation between age of sexual initiation and self-reported socioeconomic class, although these prior studies did not stratify the analysis by gender or consider interactions between sex and SES 28.

The present results also show that the prevalence of multiple sexual partners among sexually active females was $40 \%$ lower than among males, even though regional surveys indicate a rise in the number of sexual partners among Brazilian adolescents 29. Differences in prevalence might be due to female underreporting of sexual partners given Brazilian social norms 30 . Therefore, it is possible that social desirability bias could be at play in this sample, and the underestimation of the number of sexual partners among adolescent females may have led to the absence of statistically significant SES associations in these results 31 .

Among males, race/ethnicity remained a significant predictor of sexual behaviors even after controlling for household wealth and maternal education. Moreover racial/ethnic differences in sexual initiation, number of sexual partners and condom use point to a worrying pattern of racial inequality in sexual behaviors, which may put non-white males at higher risk of STIs in Brazil. These findings are in line with previous regional studies on adolescent relationships which showed that Brazilian adolescent males who self-identified as black were less likely to date and more likely to engage in short-term relationships, which could explain the higher proportion of multiple sexual partners among non-white males in this study 32 . Findings showing more prevalent risk-taking behaviors among non-white males is also corroborated by qualitative studies in Brazil and the United States, which have contextualized black males' sexual behaviors as an assertion of masculinity and defiance in the face of widespread racism and oppression 31,33 .

Living arrangement and parental supervision were also associated with sexual behaviors among both sexes, even after controlling for SES factors. Researchers have posed that adolescents in singleparent households are more likely to have had sex compared to those in dual-parent households because they might be subject to higher rates of parental absence 18 and permissive attitudes towards sex 34 . These findings show that these factors may also be at play in Brazil, since adolescents living alone, or with just one parent had higher odds of sexual initiation compared to those living with both parents. In addition, present findings show that parental supervision was positively associated with condom use and negatively related to number of sexual partners. One possible reason for these differences is that since parental supervision is typically related to parental communication 35 , adolescents may obtain more sexual education information from parents who provide closer supervision.

The absence of a significant association between SES and use of contraceptives support regional findings showing that socioeconomic class is not a predictor for this behavior among Brazilian adolescents 20. Despite overall low rates of contraceptive use, the somewhat equal distribution of use according to SES may be a reflection of national policies implemented in the last decade. These policies aimed to increase the number of free-of-charge contraceptive options in public health clinics, and to lower contraceptive prices in pharmacies catering to low-income communities 36 . However, given the cross-sectional nature of the data, it is not possible to claim a causal relation between such policies and the observed SES equality in contraceptive use.

\section{Limitations}

One notable limitation of the PeNSE data set is that it does not contain sexual orientation information. Sexual orientation is particularly relevant in the analysis of STI-related risk behaviors such as inconsistent condom use and multiple sexual partners. That is because there are known differences in sexual behaviors between LGBTQ and non-LGBTQ adolescent groups, and some of these differences are potentially mediated by SES factors 37 . Therefore, it is important to acknowledge that these findings should not rely on heteronormative assumptions of sexual behaviors, and to recognize that this sample includes a heterogeneous group of adolescents who might have different sexual orientations. 
PeNSE had some additional limitations with regards to sampling and survey content. First, since PeNSE's sampling strategy aimed at achieving national representativeness and reflecting Brazil's urbanization context 38 , only a small percentage of students from rural areas were surveyed. In addition, the survey assessed just a small number of sexual behaviors due its limited timespan and spatial coverage.

It is also worth mentioning the challenge of obtaining accurate information when assessing SES directly from adolescents who may not know specific details about their parents' educational achievement or salary ${ }^{39}$. The present results are a reflection of some of these challenges. For instance, a quarter of adolescents said they did not know their mothers' level of education. To address this, a multiple imputation procedure was performed on the variable "maternal education".

In addition, family living arrangements and parental supervision, which were hereby analyzed as moderating covariates, might be further explored as mediating moderators. This analytical approach would require using significantly different methods, which were not employed in this study.

Lastly, it is important to acknowledge that assessing youth sexual behaviors in a school setting can potentially exclude adolescents who are not attending school, which may be the most vulnerable to adverse sexual and reproductive health outcomes. For instance, adolescent mothers are more likely to drop out of school 40 , and therefore their sexual behaviors would not have been captured by the PeNSE survey.

\section{Conclusion}

This study investigated the potential association between SES and sexual behaviors among adolescents in Brazil and illustrated their complex relationship. For instance, among sexually initiated females, none of the SES variables were consistently associated with condom use, contraceptive use, and multiple sexual partners. It is possible that some of the results might be related to female underreporting of sexual behaviors, given Brazilian social norms. In contrast, one SES variable, race/ethnicity, was a significant predictor of condom use and multiple sexual partners among males. Compared to white males, non-white (black and mixed-race) males had lower odds of condom use and higher odds of having multiple sexual partners - a pattern of sexual behaviors that may put this group at a higher risk of STIs.

These findings also highlighted the important role of family structure and parental involvement in shaping adolescent sexual behaviors. For instance, odds of sexual initiation were higher among males and females living alone, compared to those living with both parents. In addition, adolescents who reported frequent parent supervision were more likely to have used a condom during last intercourse, and less likely to report having multiple sexual partners.

In conclusion, researchers should pay close attention to Brazilian gender and racial social norms when studying adolescent sexual behaviors, since they might influence not only the results, but also the collection of data. Brazilian policies aimed at reducing sexual risk behaviors among adolescents should also strive to include and support parental participation, as this can be an important protective factor, regardless of SES. Lastly, sustained efforts to broaden access to contraceptives by lowering prices and increasing availability may be examples of promising policies able to mitigate the role of SES disparities in adolescent sexual behaviors. 


\section{Contributors}

N. O. Woolley formulated the research question, conducted data analysis and wrote the manuscript. J. Macinko contributed to the study conceptualization and statistical analyses, and reviewed the manuscript.

\section{Additional informations}

ORCID: Natalia Oliveira Woolley (0000-00023780-7006); James Macinko (0000-0001-80555441).

\section{Acknowledgments}

Thanks to the reviewers for their careful reading and thoughtful insights. Special thanks to George and Benicio for their continuous encouragement and support. Finally, we thank the UCLA Graduate Summer Research Mentorship Program.

\section{References}

1. Mmari K, Sabherwal S. A review of risk and protective factors for adolescent sexual and reproductive health in developing countries: an update. J Adolesc Health 2013; 53:562-72.

2. Tolman DL, McClelland SI. Normative sexuality development in adolescence: a decade in review, 2000-2009. J Res Adolesc 2011; 21:24255.

3. Kotchick BA, Shaffer A, Forehand R, Miller KS. Adolescent sexual risk behavior: a multisystem perspective. Clin Psychol Rev 2001; 21:493-519.

4. Dehne KL, Riedner G. Sexually transmitted infections among adolescents: the need for adequate health services. Reprod Health Matters 2001; 9:170-83.

5. World Health Organization. Health for the world's adolescents: a second chance in the second decade. Geneva: World Health Organization; 2014.

6. Sedgh G, Finer LB, Bankole A, Eilers MA, Singh S. Adolescent pregnancy, birth, and abortion rates across countries: levels and recent trends. J Adolesc Health 2015; 56:223-30.

7. Bearinger LH, Sieving RE, Ferguson J, Sharma V. Global perspectives on the sexual and reproductive health of adolescents: patterns, prevention, and potential. Lancet 2007; 369:122031.

8. United Nations Children's Fund. Teenage motherhood in Latin America and the Caribbean: trends, problems and challenges. New York: United Nations Children's Fund; 2007.

9. Instituto Brasileiro de Geografia e Estatística. Censo Demografico 2010. Características da população e dos domicílios. Resultados do universo. Rio de Janeiro: Instituto Brasileiro de Geografia e Estatística; 2011.

10. Greco DB, Simão M. Brazilian policy of universal access to AIDS treatment: sustainability challenges and perspectives. Aids 2007; 21 Suppl 4:S37-45.

11. Ayres ARG, Azevedo e Silva G. Prevalência de infecção do colo do útero pelo HPV no Brasil: revisão sistemática. Rev Saúde Pública 2010; 44:963-74.

12. Rama CH, Villa LL, Pagliusi S, Andreoli MA, Costa MC, Aoki AL, et al. Awareness and knowledge of HPV, cervical cancer, and vaccines in young women after first delivery in São Paulo, Brazil - a cross-sectional study. BMC Womens Health 2010; 10:35.

13. Cavenaghi SM. Fecundidade de jovens e acesso à saúde sexual e reprodutiva no Brasil: desigualdades territoriais. In: Bruno $\mathrm{M}$, organizador. População, espaço e sustentabilidade: contribuições para o desenvolvimento do Brasil. v. 1. Rio de Janeiro: Instituto Brasileiro de Geografia e Estatística; 2015. p. 231-74.

14. Almeida MCC, Aquino EML, Barros AP. School trajectory and teenage pregnancy in three Brazilian state capitals. Cad Saúde Pública 2006; 22:1397-409. 
15. Santana DS, Cecatti JG, Parpinelli MA, Haddad SM, Costa ML, Sousa MH, et al. Severe maternal morbidity due to abortion prospectively identified in a surveillance network in Brazil. Int J Gynaecol Obstet 2012; 119:44-8.

16. Guttmacher Institute. Abortion in Latin America and the Caribbean. New York: Guttmacher Institute; 2016.

17. Centers for Disease Control and Prevention. Youth Risk Behavior Survey (YRBS): 2015 Standard Questionnaire Item Rationale. ftp:// ftp.cdc.gov/pub/data/yrbs/2015/2015_stan dard_itemrationale.pdf (accessed on 16/Apr/ 2016).

18. Santelli JS, Lowry R, Brener ND, Robin L. The association of sexual behaviors with socioeconomic status, family structure, and race/ ethnicity among US adolescents. Am J Public Health 2000; 90:1582-8.

19. Harling G, Subramanian SV, Barnighausen T, Kawachi I. Socioeconomic disparities in sexually transmitted infections among young adults in the United States: examining the interaction between income and race/ethnicity. Sex Transm Dis 2013; 40:575-81.

20. Rocha CLA, Horta BL, Pinheiro RT, Cruzeiro ALS, Cruz S. Use of contraceptive methods by sexually active teenagers in Pelotas, Rio Grande do Sul State, Brazil. Cad Saúde Pública 2007; 23:2862-8.

21. Sanchez ZM, Nappo SA, Cruz JI, Carlini EA, Carlini CM, Martins SS. Sexual behavior among high school students in Brazil: alcohol consumption and legal and illegal drug use associated with unprotected sex. Clinics 2013; 68:489-94.

22. Oliveira-Campos M, Nunes ML, Madeira FC, Santos MG, Bregmann SR, Malta DC, et al. Sexual behavior among Brazilian adolescents, National Adolescent School-based Health Survey (PeNSE 2012). Rev Bras Epidemiol 2014; 17 Suppl 1:116-30.

23. Instituto Brasileiro de Geografia e Estatística. Pesquisa Nacional de Saúde do Escolar 2015. Rio de Janeiro: Instituto Brasileiro de Geografia e Estatística; 2016.

24. Global School-based Student Health Survey. GSHS Bibliography 2012. http://www.who. int/ncds/surveillance/gshs/GSHS_Bibliogra phy.pdf?ua =1 (accessed on 10/Apr/2018).

25. Braveman P, Cubbin C, Marchi K, Egerter S, Chavez G. Measuring socioeconomic status/ position in studies of racial/ethnic disparities: maternal and infant health. Public Health Rep 2001; 116:449-63.

26. Instituto Brasileiro de Geografia e Estatística. Síntese de indicadores sociais: uma análise das condições de vida da população brasileira, 2016. http://biblioteca.ibge.gov.br/visua lizacao/livros/liv98965.pdf (accessed on 14/ Jun/2017)

27. DiClemente RJ, Salazar LF, Crosby RA. A review of STD/HIV preventive interventions for adolescents: sustaining effects using an ecological approach. J Pediatr Psychol 2007; 32:888906.
28. Hugo TDO, Maier VT, Jansen K, Rodrigues CEG, Cruzeiro ALS, Ores LC, et al. Fatores associados à idade da primeira relação sexual em jovens: estudo de base populacional. Cad Saúde Pública 2011; 27:2207-14.

29. Arroyave LJO, Restrepo-Méndez MC, Horta BL, Menezes AMB, Gigante DP, Gonçalves $\mathrm{H}$. Tendências e desigualdades nos comportamentos de risco em adolescentes: comparação das coortes de nascimentos de Pelotas, Rio Grande do Sul, Brasil. Cad Saúde Pública 2016; 32:e00120215.

30. Borges ALV, Nakamura E. Social norms of sexual initiation among adolescents and gender relations. Rev Latinoam Enferm 2009; 17:94100.

31. Guerriero I, Ayres JR, Hearst N. Masculinity and vulnerability to HIV among heterosexual men in São Paulo, Brazil. Rev Saúde Pública 2002; 36:50-60.

32. Camargo BV, Giacomozzi AI, Wachelke JFR, Aguiar A. Relações amorosas, comportamento sexual e vulnerabilidade de adolescentes afrodescendentes e brancos em relação ao HIV/ aids. Saúde Soc 2010; 19 Suppl 2:36-50.

33. Bowleg L. Love, sex, and masculinity in sociocultural context. Men Masc 2004; 7:166-86.

34. Davis EC, Friel LV. Adolescent sexuality: disentangling the effects of family structure and family context. J Marriage Fam 2001; 63:66981.

35. DeVore ER, Ginsburg KR. The protective effects of good parenting on adolescents. Curr Opin Pediatr 2005; 17:460-5.

36. Portal Brasil. Planejamento familiar 2011. http://www.brasil.gov.br/saude/2011/09/ planejamento-familiar (accessed on 28/Jul/ 2014).

37. Fields E, Morgan A, Sanders RA. The intersection of sociocultural factors and health-related behavior in lesbian, gay, bisexual, and transgender youth: experiences among young black gay males as an example. Pediatr Clin North Am 2016; 63:1091-106.

38. Instituto Brasileiro de Geografia e Estatística. ONU e IBGE divulgam relatórios de população. http://www.ibge.gov.br/home/presiden cia/noticias/11122001 onu.shtm (accessed on 07/Feb/2015).

39. Currie CE, Elton RA, Todd J, Platt S. Indicators of socioeconomic status for adolescents: the WHO Health Behaviour in School-aged Children Survey. Health Educ Res 1997; 12:38597.

40. Binstock G. Fecundidad y maternidad adolescente en el Cono Sur: apuntes para la construcción de una agenda común. Panamá: Fondo de Población de las Naciones Unidas; 2016. 


\section{Resumo}

Ainda que adolescentes de estado socieconômico baixo tenham taxas mais altas de desfechos adversos de saúde sexual e reprodutiva, as evidências sobre a associação entre estado socieconômico e comportamentos sexuais é menos consistente. Uma análise seccional da associação entre características sociodemográficas (renda familiar, escolaridade materna e raça/cor) e comportamentos sexuais (iniciação sexual, múltiplos parceiros sexuais, uso inconsistente de preservativo e uso inconsistente de contracepção) de adolescentes brasileiros foi realizada com base na Pesquisa Nacional de Saúde do Escolar (PeNSE) de 2015, um inquérito de representatividade nacional baseado em escolas com 102.301 adolescentes. As análises incluíram modelos logísticos multivariáveis levando em consideração características geográficas e familiares. Cerca de 27,5\% dos adolescentes já haviam tido a primeira relação sexual. A renda domiciliar estava associada com a iniciação sexual feminina, enquanto raça/cor estava associada com uso de preservativo e múltiplos parceiros sexuais para os adolescentes. Por exemplo, adolescentes pretos tinham uma probabilidade $35 \%$ maior de ter múltiplos parceiros (ORa = 1,35; IC95\%: 1,13-1,62), mas uma probabilidade $22 \%$ menor de usar preservativo (ORa =0,78; IC95\%: 0,65-0,94), quando comparados a adolescentes brancos. A supervisão parental frequente estava positivamente associada ao uso de preservativo (sexo feminino: $O R a=1,28$; IC95\%: 1,10-1,49 e sexo masculino: $O R a=1,33$; IC95\%: 1,18-1,49). Os resultados demonstram as relações complexas entre estado socieconômico e comportamentos sexuais. Pesquisadores devem prestar atenção nas normas de gênero, raciais e sociais relevantes para comportamentos sexuais em adolescentes, dado que elas podem influenciar a coleta de dados e os resultados. Politicas públicas nacionais também devem apoiar supervisão parental ativa, dado que esse pode ser um fator protetor.

Comportamento Sexual; Classe Social; Adolescente; Estudantes

\section{Resumen}

Pese a que los adolescentes que proceden de estratos socioeconómicos bajos sufren altas tasas relacionadas con problemas de su estado de salud reproductiva y sexual, las evidencias de asociación entre estratos socioeconómicos bajos y sus comportamientos sexuales han sido menos consistentes. En este estudio, se llevó a cabo un análisis trasversal de la asociación entre las características sociodemográficas (ingresos familiares, educación materna y raza/etnicidad) y comportamientos sexuales (iniciación sexual, múltiples parejas sexuales, uso ocasional del condón, al igual que de métodos anticonceptivos) con adolescentes brasileños, usando la Encuesta Nacional de Salud Escolar (PeNSE) del año 2015, una encuesta representativa a nivel nacional, basada en 102.301 adolescentes en edad escolar. Los análisis incluyeron modelos logísticos multivariables, que tuvieron en cuenta las características geográficas y familiares. Cerca de un $27,5 \%$ de los adolescentes ya estaban sexualmente iniciados. Los ingresos familiares estuvieron asociados con la iniciación sexual de la mujer, mientras que la raza/etnicidad estuvo asociada con el uso del condón y múltiples parejas sexuales entre los hombres. Por ejemplo, los hombres negros tenían un 35\% mayores posibilidades de contar con múltiples parejas ( $a O R=1,35$; IC95\%: 1,13-1,62), pero un 22\% menos posibilidades de usar el condón ( $a O R=0,78$; IC95\%: 0,65-0,94), comparados con los hombres blancos. La supervisión frecuente de los padres estuvo positivamente relacionada con el uso del condón (mujeres; $a O R=$ 1,28; IC95\%: 1,10-1,49, y hombres; $a O R=1.33$; IC95\%: 1.18-1,49). Los resultados muestran la compleja relación entre estratos socioeconómicos bajos y los comportamientos sexuales. Los investigadores deberían prestar atención al género, las pautas raciales y sociales para los comportamientos sexuales de los adolescentes, puesto que pueden influenciar la recogida de datos y resultados. Las politicas nacionales deberían apoyar la supervisión de los padres, puesto que puede tratarse de un factor protector.

Conducta Sexual; Clase Social; Adolescente; Estudiantes
Submitted on 06/Dec/2017

Final version resubmitted on 24/Aug/2018

Approved on 31/Aug/2018 